\title{
TRADITION OF CYNICISM: FROM ORIGIN TO NOWADAYS
}

\author{
Valentina Kudriavtseva $^{1 *}$, YuliaTsiplakova ${ }^{2}$ \\ ${ }^{1}$ Assoc. Prof. Dr., Ural FederalUniversity, RUSSIA, remidosi@gmail.com \\ ${ }^{2}$ Assoc. Prof. Dr., Ural FederalUniversity, RUSSIA, j.ceplakova@gmail.com \\ ${ }^{*}$ Corresponding author
}

\begin{abstract}
Cynicism commonly is interpreted as a moral phenomenon. However this understanding of cynicism is not completed. It is necessary to analyze the tradition of cynicism as a philosophical and cultural phenomenon. The cynicism is especially popular during the periods of crisis, amid the breakdown of ideologies and religious doctrines. The tradition of cynicism is inseparable from the history of kynicism. Nowadays the phenomenon of cynicism is widely spread in the Western world. In accordance with the philosophy of Peter Sloterdijk contemporary mass consciousness in the West is characterized by universal diffusive cynicism. In the opposition to diffusive cynicism Peter Sloterdijk develops an original philosophical theory called neokynicism.
\end{abstract}

Keywords: Cynicism, crisis, kynicism, Enlightenment, diffusive cynicism, consciousness, reason, neokynicism

\section{INTRODUCTION}

The tradition of cynicism originates in antiquity. The phenomenon of cynicism is associated primarily with the philosophical school of the kynics which was founded in Athens of V-IV centuries BC. Researchers believe the origin of kynicism to be historically due to the disappointment in the values of the ancient society.

There are also formulations where kynicism is defined as a way of life, the world view, a special system of views based on the denial of laws and norms. This system is characterized by the neglect of the dominant ideology.

The ambiguity in the assessments of this cultural phenomenon is associated with the separation of the phenomenon of cynicism into kynicism, pseudo-kynicism and cynicism. The study of this process is of scientific and current interest because the cynicism as a cultural and social phenomenon actively manifests itself in the periods of cultural crisis. The doctrine of the kynics was a classic Socratic school and was based 
on the pursuit of virtue. However, with time a negative attitude towards kynics was formed which led to the separation of cynicism into the independent phenomenon.

\section{FROM KYNICISM TO CYNICISM}

\subsubsection{Origin of Cynicism}

There are three main reasons which contributed to the creation of a negative image of kynicism. The first one is an incorrect interpretation of the first kynics' ideas, due to their the specific lifestyle; hence the second reason - the fashion in late antiquity for pseudo-kynicism, which is a distorted form of kynicism brought to absurdity; the third reason is the presence of a negative connotation in the name of the school. All of these led to the cynicism being interpreted as a negative moral phenomenon.

Additionally, the cynicism absorbed the worst aspects of kynicism (Navia, 1996, p.4). When the relevance of kynicism was exhausted by a historical reality the deformation of the basic ideas of kynic philosophy began. There were contradictions between the way of life and proclaimed slogans. It's amazing how such a bright teaching aimed at achieving of virtue could turn into the opposite by which we mean a phenomenon called nowadays cynicism. Usually the cynicism means the disregard for the norms of morality, and is revealed as the opposite of virtue.

Unlike nihilism, where there is a complete denial, and skepticism which is based on doubt, cynicism implies disbelief and challenge, exposure to the problem. The origins of this are, of course, in the kynicism. Kynicism is characterized as a challenge to public morality; lack of ownership; simplicity in everyday life; the irony in the assessment; it provokes a demonstration of action; naturalism (Goldfarb, 1991, p.30). Diogenes became a symbol of ideal free sage, who brought his needs to a minimum. The cult of nature in its moral sense, the preaching of simplicity, harmony between man and nature, honest and virtuous poverty, the rejection of benefits of material, culture and civilization, criticism of the power, all of above inspired poor wandering monks of the middle ages and the reformers of the XVI - XVII centuries (Navia, 2005, p.3). The ideal of natural rights and natural equality of people found supporters among the revolutionary thinkers of the XVIII and XIX centuries (Nachov, 1982, p.218).

\subsubsection{F. Nietzche as a First Neokynic}

Nietzsche gave a new impulse to the kynicism within the tradition of cynicism.Sloterdijk called him the first postmodern neokynic, believed that Nietzsche's colorful manner of writing was a kind of literary "guerrilla war" against the great truths of philosophy. This "war" was against all the laws of philosophy and philology.

Nietzsche abandoned the metaphysics, the knowledge of which has the same significance as for "the sailor among the dangers of the storm sea knowledge of the chemical analysis of water" (Nietzsche, 1990 pp. 243244). Dogmatic adherence to the metaphysics demonstrates illness, weak vitality of thoughts. Nietzsche opposes the vitality, health, strength to weakness, death. Metaphysic characterizes of the philosophical tradition, the symbol of which is Socrates, as well as for the ancient kynics. The opposition is "alive, healthy, strong, easy against the dying, bounding, heavy" suggested form of presentation of Nietzsche's ideas. From metaphysical concepts Nietzsche turned to the myths, the images, highlighting his break with metaphysics.

The connection in the culture of the mythological forces of Dionysus and Apollo personified energy, power of vitality, but at the same time concentrated in an individual, specific aspect. Nietzsche urges the thinking man to free his mind from the domination of metaphysical concepts, normativity, rational frames and become a "free mind". Similar to listening to the chorus in a Greek tragedy, the spectator can think about how that singing affects him personally. We can say that "free mind" is an intermediate stage between the metaphysics, religion, morality and the mysterious "Übermensch", whose image belongs to the future.

The philosopher Friedrich Nietzsche showed that social morality is not only morality and isn't unconditional. He believed that the advanced and promising concept of practical reason put forward by Kant on the canons of the Enlightenment weakened. The categorical imperative does not work. Inside the world, which combines rationality of Hegel, Schopenhauer's will, the desire for Feuerbach's earthly happiness hides many contradictions. On the one hand there are weak lifeless shell social norms, on the other hand the desire of a man full of life and creativity.

The state of the "free mind" is achieved through a decisive break with the dominant metaphysical and moralreligious tradition. As a result, a person renounces his duty to the state, faith and even relatives, thus putting forward a challenge to society. In this state, a person becomes free, closer to the ideal of kynics. 


\subsubsection{The Concept of Cynicism by P. Sloterdijk}

The most famous person that can be considered in the context of neokynism today is a German philosopher and cultural historian Peter Sloterdijk (1947). In his "Critique of cynical reason" P. Sloterdijk considers the historical evolution of cynicism and outlines three approaches to the definition of cynicism:

- The intuitive approach defines cynicism as enlightened false consciousness;

- The historical approach shows cynicism as an instrument of polemics of power, "know what they are doing", there is a division between cynicism and kynicism;

- The phenomenological approach regards cynicism as the result of a polemic between different forms of consciousness.

The philosophy of Sloterdijk is a philosophy of the turn of the 20th and 21st centuries, that is, the time during which the continuation and completion of the processes that began during the Enlightenment period was found. The main contradiction of this era P. Sloterdijk considers the clash of enlightened and ordinary consciousness, which has given rise to contemporary cynicism. In the twentieth century, intensify the contradiction between the system of humanistic values that was built by enlightenment and their successors for three centuries, and a well-developed and differentiated scale of consumer values in which spirituality no longer exists. When these two systems of values, which we will conditionally call enlightenment and consumer, collide in the same consciousness, it is precisely according to P. Sloterdijk that contemporary cynicism arises.

Sloterdijk's cynicism gives the following definition: "cynicism is enlightened false consciousness." This consciousness, learned in the educations of humanistic ideas about truth, goodness and beauty, but not wishing to follow these ideas, because guided by consumer considerations. This gap between rational and real, between knowing how to do it and the act itself is a situation when a person may not take any unequivocal position in society.

Thus modern man has broken consciousness: in one half - enlightenment, with its ideals of equality, brotherhood, justice, reasonable and meaningful life, in the other half - the realization that the need to get money for food forces us to live contrary to these ideals, to follow the rules opposite to them.

Sloterdijk reveals the main secret of modern cynicism: the enlightened man is just a hypocrite who concealed high moral standards of the Enlightenment, and lives in accordance with the values of the consumer society. The cynic lives a life of the consumer, seeking joy and pleasure, but does not hide this fact.

According to the concept Sloterdijk, the allocation of cynicism also associated with the struggle of ideologies. P. Sloterdijk cynicism polarizes the kynicism of "bottom" and cynicism of the "top". Ancient kynicism is the first philosophical attack on culture; it is a way to expose the truth is the opportunity to debate from a position of positive audacity.

As an ancient kynicism was the call of the plebs idealism and contemporary cynicism of the elite is a call to idealism as an ideology. According to Sloterdijk the more modern a society without an alternative, the more it becomes a cynic. Even being opposing each other, the cynicism of the plebeians and the cynicism of the elite are both ways of expressing contempt for the masses.

\section{P. Sloterdijk reveals the history of cynicism in the form of a panopticon.}

The first figure in the panopticon is Diogenes of Sinope. He is a kynic, anti-theoretician, anti-dogmatician, who publicly stands in opposition to the established moral and political standards. When intellectuals abandoned the kynical abstinence, turning to the search of comfort, the situation changed.

The second figure is Lucian the scoffer. He acts as the element of elite's satire against the intellectual simpletons. This is transition kynical forma of the plebeian and humorous critique of culture in the elite's cynical satire.

The third figure in the panopticon is Mephistopheles. He is an expression of the essence of the bourgeois cultural revolution as an opportunity to call a spade a spade. This eclectic figure, which is closely intertwined modernity and antiquity, dialectical evolutionism and the philosophy of nature. Damn Goethe is a guide to the kynical and cynical empiricism.

Further, the panopticon appears to the figure of Grand Inquisitor from the novel of F. Dostoevsky "The Brothers Karamazov". Grand Inquisitor is the prototype of the modern political cynic (Dostoevsky, 1991, pp. 277-293). He symbolized two poles of the conscious and thinking. On the one hand, a realist, moralist and a 
cynic, on the other, the utopian, the romantic and hyper-moralist. Holders of power also held a knowledge, decide whom, when, and how much truth there is to provide. Cynicism means connected with the moralism of the goals. It is the first form of cynical consciousness, which develops in the nineteenth century.

Completes the panopticon "Das Man", which describes Heidegger. "Das Man" or without a person, the undefined everyday self, publicity, in relation to which always correct average parameters. "Das Man" does not seek to realize your own existence and understand the nature of things (Heidegger, 2008, p.126). Sloterdijk considers "Das Man" as a real subject of modern diffuse cynicism.

In the modern world cynicism has acquired a mass character. Due to diffusely, cynicism has spread to all spheres of human activity.

In the kynical tradition is vividly expressed a desire for individuality, for difference from the crowd. In the modern cynic, according to Sloterdijk, this is the average social character in the society.

Antique kynicism differs from modern cynicism the fact that kynic was a tiny minority in society. That society liked a funny clown of kynicism. This fool was allowed to say everything that is normally forbidden. That is why P. Sloterdijk calls cynicism a genuine realism, pointing to the firm establishment of the cynicism in the public mind.

\section{CONCLUSION}

The ideological evolution of cynicism begins with the kynical doctrine of the Greek sages. Howeverkynical the motives are manifested in various spheres of social life for several centuries, up to modern times. Modern consciousness of the masses in the West characterizes the universal diffuse cynicism. Each individual roped and subdued the existing social system. One part of his consciousness, the individual criticizes the system, and the other subordinate. Cynicism can be presented as a final product of degradation "enlightened false consciousness". This consciousness knows the highest achievements of human culture, but denies them in the theory and in practice.

Cynics are almost all modern people following the principles of the Enlightenment, but in practice, using violence, manipulation and exploitation.

Contrasting diffuse cynicism is neokynism in which humor and satire are used to mask a noble humanist and a champion of human rights to unmask a mercenary and selfish nature with evil will. Under the guise of enlightened rhetoric people achieve their goals and defend personal interests. Therefore, enlightened cynic follows his egoism demands of his will, while not considering himself a bad person. Someone who literally understands the requirement to comply with the ethics of reason and humanism is not viable.

Periodically there are times that differ a cynical attitude era, when ideology becomes reflexive, the era in which the norms and dogmas of a culture, faded and permeated with irony in relation to itself, start to play with its internal contradictions. Because cynicism leads to a deadlock, in times of chronic crisis, when dulled vitality, when there are no positive experiences, the alternative is kynicism. Kynicism is a philosophy of life in a time of crisis. It teaches us to restrict needs, to show fortitude and resourcefulness to take what this moment offers (Sloterdijk, 2001, p.214).

We can assume that as a protest against tradition and challenge the imposed rules, kynic "audacity" to be in demand in the future, because kynicism as a form of individualization and the opposition of the mass is a necessary requirement for the members of any society.

\section{REFERENCE LIST}

Dostoevsky F. M. (1991) The Brothers Karamazov. Vol. 9.

Goldfarb, J. C. (1991). The Cynical Society: The Culture of Politics and the Politics of Culture in American Life.

Nachov, I. M. (1982) The Philosophy of the kynics.

Navia L. E. (1996) Classical cynicism: a critical study 
Navia, L. E. (2005) Diogenes The Cynic: The War Against The World.

Nietzsche, F. (1990) Human, all too human. Vol. 1.

Heidegger M. (2008). Being and Time.

Sloterdijk, P. (2001) Critique of cynical reason. 